\title{
Predation effects of Melanoides tuberculatus (Müller 1774) on periphytic biofilm colonization: an experimental approach
}

Janiele França Vasconcelos ${ }^{1,4}$, José Etham de Lucena Barbosa ${ }^{2}$, Evaldo de Lira Azevêdo ${ }^{2}$,

Daniele Jovem da Silva Azevêdo ${ }^{2}$ \& Maria José Pinheiro Anacleto ${ }^{3}$

${ }^{1}$ Programa de Pós-graduação em Ecologia de Ambientes Aquáticos, Universidade Estadual de Maringá - UEM, Av. Colombo, 5790, Jardim Universitário, CEP 87020-900, Maringá, PR, Brasil. www.uem.br

${ }^{2}$ Programa de Pós-graduação em Ecologia e Conservação, Universidade Estadual da Paraíba - UEPB, Rua Baraúnas, 351, Universitário, CEP 58429-500, Campina Grande, PB, Brasil. www.uepb.edu.br

${ }^{3}$ Departamento de Biologia, Complexo Laboratorial de Pesquisa Três Marias, Universidade Estadual da Paraíba-UEPB, Rua Baraúnas, 351, Sala 15, $1^{\circ}$ andar, Universitário, CEP 58429-500, Campina Grande, PB, Brasil. www.uepb.edu.br

${ }^{4}$ Corresponding author: Janiele França Vasconcelos, e-mail: janiele.biologa@gmail.com

VASCONCELOS, J.F., BARBOSA, J.E.L., AZEVÊDO, E.L., AZEVÊDO, D.J.S. \& ANACLETO, M.J.P. Predation effects of Melanoides tuberculatus (Müller 1774) on periphytic biofilm colonization: an experimental approach. Biota Neotrop. 13(2): http://www.biotaneotropica.org.br/v13n2/en/abstract?article+bn03613022013

Abstract: The present study evaluated the predation effects of the gastropod Melanoides tuberculatus on the taxa richness and density of the periphyton community. A laboratory experiment was conducted with two treatments: control (without M. tuberculatus) and with M. tuberculatus, each treatment being replicated four times. For periphyton colonization, glass slides were placed in $3.5 \mathrm{~L}$ of water from the environment of the gastropods. The analysis of species richness and density of the periphyton community on these artificial substrates showed significant differences $(\mathrm{p}<0.05)$ between treatments. In the treatment with $M$. tuberculatus, taxa richness and density were lower, with a predominance of Chantrasia macrospora in the last days of the experiment. It follows that predation by $M$. tuberculatus destabilizes the course of periphyton colonization, suggesting the possibility of disruption of natural food chains, however, more studies are needed in this perspectives.

Keywords: invasive species, herbivory, laboratory experiment, Melanoides tuberculatus, periphyton.

VASCONCELOS, J.F., BARBOSA, J.E.L., AZEVÊDO, E.L., AZEVÊDO, D.J.S. \& ANACLETO, M.J.P. Efeitos da predação de Melanoides tuberculatus (Müller 1774) sobre a comunidade perifítica: uma abordagem experimental. Biota Neotrop. 13(2): http://www.biotaneotropica.org.br/v13n2/pt/abstract?article+bn03613022013

Resumo: O presente estudo teve como objetivo avaliar os efeitos da predação de Melanoides tuberculatus sobre a riqueza de táxons e densidade da comunidade perifítica. Foi realizado experimento em laboratório, com dois tratamentos: controle (ausência de M. tuberculatus) e com M. tuberculatus, sendo cada tratamento replicado quatro vezes. Para a colonização da comunidade perifítica foram colocados 3,5 L de água do ambiente de origem dos gastrópodes, em cada tratamento e $49 \mathrm{~cm}^{2}$ de substrato previamente colonizado e 20 lâminas como substratos artificiais, durante 24 dias. A análise da riqueza de táxons e densidades da comunidade perifítica nos substratos artificiais mostrou diferença $(\mathrm{p}<0,05)$ entre os tratamentos. Os tratamentos com M. tuberculatus apresentaram menor riqueza e densidade, com predominância da Chantrasia macrospora nos últimos dias do experimento. Conclui-se que a predação do $M$. tuberculatus desestabiliza o curso da colonização do perifiton e consequentemente pode causar a ruptura das cadeias naturais, contudo mais estudos nessa perspectiva são necessários.

Palavras-chave: espécies invasoras, herbivoria, experimento em laboratório, Melanoides turbeculatus, perifiton. 


\section{Introduction}

Invasive species have been widely discussed from ecological, agricultural and economic aspects, particularly with regard to the negative effects of these organisms on native species (Pointier et al. 1998). These effects are related to competition, parasitism, predation (Facon et al. 2005), decrease of local biodiversity and transformation of habitats (Santos et al. 2007).

The red-rimmed melania Melanoides tuberculatus is an AfroAsian Thiaridae gastropod (Pilsbry \& Bequaert 1927), which was introduced into Latin America in the late 1960s and is now widespread in almost all regions (Brown 1994, Fernandez et al. 2003). The first record of this species in Brazil was in 1967, in Santos, state of São Paulo (Vaz et al. 1986), probably introduced along with fish and ornamental plants from Africa (Santos \& Eskinazi-Sant'Anna 2010). This snail has a high capacity for colonization and adaptation to new habitats, and can limit or exclude the native species (Guimarães et al. 2001, Giovanelli et al. 2003). M. tuberculatus is frequently found associated with biofilm because of its preference for feeding on green algae and organic matter (Beeston \& Morgan 1979).

The periphyton biofilm is established on hard substrates of aquatic ecosystems and plays an important role as primary producers, food source for invertebrates, and bio-indicators of environmental quality (Szabó et al. 2008). During the colonization process, the periphyton community is affected by many factors such as area of the substrate, and the physical, chemical and morphological features of the aquatic system (Moschini-Carlos et al. 2000). Predation may have a significant negative effect on the dynamics of periphyton colonization (Blanchet et al. 2008). M. tuberculatus had a substantial success colonizing Brazilian aquatic ecosystems (Santos \& EskinaziSant'Anna 2010), but low information has been produced about the your predation effects on dynamic of algae community and the consequences for the other trophic levels.

This study analyzed the effects of $M$. tuberculatus on periphyton biofilm colonization. We hypothesized that the presence of $M$. tuberculatus affects the taxa richeness, and density of the periphyton biofilm.

\section{Material and Methods}

The effect of $M$. tuberculatus on periphyton biofilm colonization was tested in aquariums, under laboratory conditions. The experiment was conducted during 24 days, between February and March of 2012, in the Laboratório de Ecologia Aquática of the Universidade Estadual da Paraíba (LEAq/UEPB).

The experimental design was composed by two treatments, replicated four times: control, without (TC) and with $M$. tuberculatus (TM). The aquariums were arranged in rows (Figure 1), and kept at a temperature of $25^{\circ} \mathrm{C}$ and 12/12-h photoperiod. Glass slides (25) were arranged on the sides of the aquariums for periphyton colonization (Figure 1). The aquariums were filled with natural water $(3.5 \mathrm{~L})$ from the Bodocongó Reservoir, enriched with $\mathrm{N}\left(1.25 \mathrm{~mL} \mathrm{NaNO}_{3}\right.$ $\left.\left[10,000 \mathrm{mg} \mathrm{N} . \mathrm{L}^{-1}\right]\right)$ and $\mathrm{P}\left(1.25 \mathrm{~mL} \mathrm{KH}_{2} \mathrm{PO}_{4}\left[1,600 \mathrm{mg}\right.\right.$ P.L $\left.\left.{ }^{-1}\right]\right)$, at the start of the experiment and in the $3^{\text {rd }}$ week. In the TM treatments, 22 adult individuals of $M$. tuberculatus, with a total biomass of 7.56 $\mathrm{mg}$, were placed in each TM aquarium.

\section{Samples and data analyses}

Samples were taken every three days for four weeks, and consisted of randomly chosen glass slides. The periphyton was removed from the slides with the aid of stainless-steel blades and jets of distilled water. The material was stored in PVC bottles, and fixed and preserved with acetic Lugol for quantitative analysis. Periphytic algae were counted under a inverted microscope, using method of Utermöhl (1958). Random fields were counted to achieve stabilization of the curve (species rarefaction), up to a total of 100 individuals of the most common species (Bicudo 1990). The density of periphytic algae was calculated according to equation of Ros (1979). At the end of the experiment, the individuals of $M$. tuberculatus were counted and the final biomass was determined.

A Kruskal-Wallis test was performed to determine the differences in species richness, density, and diversity of periphytic algae in the treatments and among the days of colonization. This analysis was executed in the software Statistica 7.1. An nMDs was used to determine the differences in species composition between the treatments, and an ANOSIM to confirm the ordination patterns in nMDS, using PRIMER-PERMANOVA software.

\section{Results}

The periphytic algae from the two treatments represented a total of 35 taxa from the following divisions: Chlorophyceae (23\%),

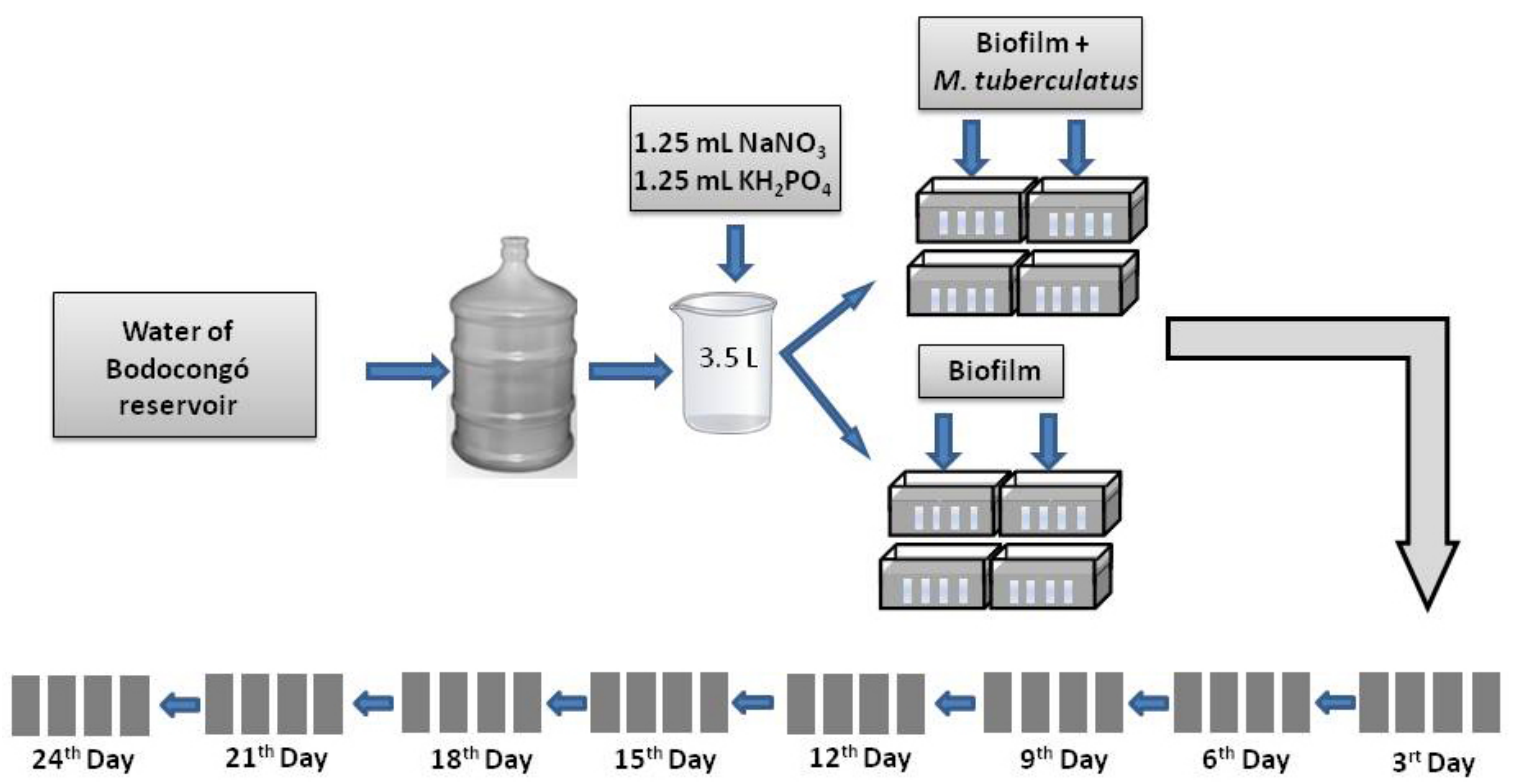

Figure 1. Experimental design with control and treatment with Melanoides tuberculatus, February 28 - March $23,2012$. 
Cyanobacteria (23\%) Bacillariophyceae (34\%), Euglenophyceae (11\%), Zygnemaphyceae (3\%), Oedogoniophyceae (3\%) and Florideophyceae $(3 \%)$. In the control treatment, 32 taxa were recorded, with 18 exclusive taxa; 17 were recorded in the treatment with M. tuberculatus, with three exclusive species (Table 1).

Taxa richness showed significant differences between treatments $(\mathrm{p}<0.05)$ and between sampling periods for TC $(\mathrm{p}<0.05)$. In the early stages of colonization, higher taxa richness was observed for the TM; however, from the 6th day of the experiment, richness decreased, ranged to 4-2 taxa and continued to decline until the end of the experiment. For the control treatment, taxa richness increased until the 9th day, then decreased and a new "surge" of species occurred in the 21 th days (Figure 2A).
The density of periphytic algae showed significant differences between treatments $(\mathrm{p}<0.05)$, with higher densities in the control treatment. The density increased during the experiments, with lower values in the early stages, exponential growth from day 3 th, and peaking at day 12 th in the control treatment and on the 9th day in the TM treatment (Figure 2B).

Diatoms were most abundant in the TC (62\% of total density), followed by Cyanobacteria (19\%) and Chlorophyceae (7\%). Navicula sp. was dominant at the beginning of colonization (up to day 6) and Cyclotella meneguiniana subsequently. The more abundant species were Planktothrix agardii, Leptolyngbya sp., Oedogonium sp. and Spirogyra sp. (Figure 3A).

Table 1. Composition of periphytic algae in the experiment with control TC and treatment with Melanoides tuberculatus TM, February 28 - March $23,2012$.

\begin{tabular}{|c|c|c|}
\hline Taxon & TC & TM \\
\hline \multicolumn{3}{|l|}{ Bacillariophyceae } \\
\hline Amphipleura sp Kützing 1844 & $\mathrm{X}$ & \\
\hline Amphora sp Ehrenberg ex Kützing 1844 & $\mathrm{X}$ & \\
\hline Cocconeis sp Ehrenberg 1837 & & $\mathrm{X}$ \\
\hline Cyclotella meneghiniana Kützing 1844 & $\mathrm{X}$ & $\mathrm{X}$ \\
\hline Eunotia sp Ehrenberg 1837 & $\mathrm{X}$ & $\mathrm{X}$ \\
\hline Fragilaria capucina Desmazières 1830 & $\mathrm{X}$ & $\mathrm{X}$ \\
\hline Navicula sp Bory de Saint-Vincent 1822 & $\mathrm{X}$ & $\mathrm{X}$ \\
\hline Navicula $\mathrm{sp} 2$ & & $\mathrm{X}$ \\
\hline Nitzschia longíssima (Brébisson) Ralfs in Pritchard 1861 & $\mathrm{X}$ & $\mathrm{X}$ \\
\hline Surirella sp Turpin 1828 & $\mathrm{X}$ & $\mathrm{X}$ \\
\hline Synedra sp Ehrenberg 1830 & $\mathrm{X}$ & $\mathrm{X}$ \\
\hline Synedra ulna (Nitzsch) Ehrenberg 1832 & $\mathrm{X}$ & \\
\hline \multicolumn{3}{|l|}{ Chlorococcaceae } \\
\hline Chlorella vulgaris Beyerinck 1890 & $\mathrm{X}$ & $\mathrm{X}$ \\
\hline Chlorococcum sp Meneghini 1842 & $\mathrm{X}$ & \\
\hline Crucigenia sp Morren 1830 & $\mathrm{X}$ & \\
\hline Desmodesmus quadricaudatus (Arkansas) Smith 2010 & $\mathrm{X}$ & \\
\hline Eutetramorus sp Walton 1918 & $\mathrm{X}$ & $\mathrm{X}$ \\
\hline Monoraphidium contortum Komárková-Legnerová in Fott 1969 & $\mathrm{X}$ & \\
\hline Oocystis borgei Snow 1903 & $\mathrm{X}$ & \\
\hline Schroederia antillarum (Komárek) Hegewald \& Schnepf 1986 & $\mathrm{X}$ & \\
\hline \multicolumn{3}{|l|}{ Cyanophyceae } \\
\hline Aphanocapsa elegans (Lemmermann) Joosten 2006 & $\mathrm{X}$ & \\
\hline Leptolyngbya nodulosa Li \& J.Brand 2007 & $\mathrm{X}$ & $\mathrm{X}$ \\
\hline Lyngbya sp Agardh ex Gomont 1892 & $\mathrm{X}$ & $\mathrm{X}$ \\
\hline Merismopedia mínima Beck 1897 & $\mathrm{X}$ & \\
\hline Microcystis protocystis Crow 1923 & $\mathrm{X}$ & \\
\hline Oscillatoria sp Vaucher ex Gomont 1892 & $\mathrm{X}$ & \\
\hline Planktothrix agardhii Gomont Anagnostidis \& Komárek 1988 & $\mathrm{X}$ & \\
\hline Pseudanabaena galeata Böcher 1949 & $\mathrm{X}$ & $\mathrm{X}$ \\
\hline \multicolumn{3}{|l|}{ Euglenophyceae } \\
\hline Euglena pusilla Playfair 1921 & $\mathrm{X}$ & $\mathrm{X}$ \\
\hline Lepocinclis salina Fritsch 1914 & $\mathrm{X}$ & \\
\hline Strombomonas sp Deflandre 1930 & $\mathrm{X}$ & \\
\hline Trachelomonas sp Ehrenberg 1835 & $\mathrm{X}$ & $\mathrm{X}$ \\
\hline \multicolumn{3}{|l|}{ Florideophyceae } \\
\hline Chantransia macrospora Wood 1887 & & $\mathrm{X}$ \\
\hline \multicolumn{3}{|l|}{ Oedogoniophyceae } \\
\hline Oedogonium sp Link ex Hirn 1900 & $\mathrm{X}$ & \\
\hline \multicolumn{3}{|l|}{ Zygnematophyceae } \\
\hline Spirogyra sp Link 1820 & $\mathrm{X}$ & \\
\hline
\end{tabular}


Predation effects of Melanoides tuberculatus on periphytic biofilm colonization
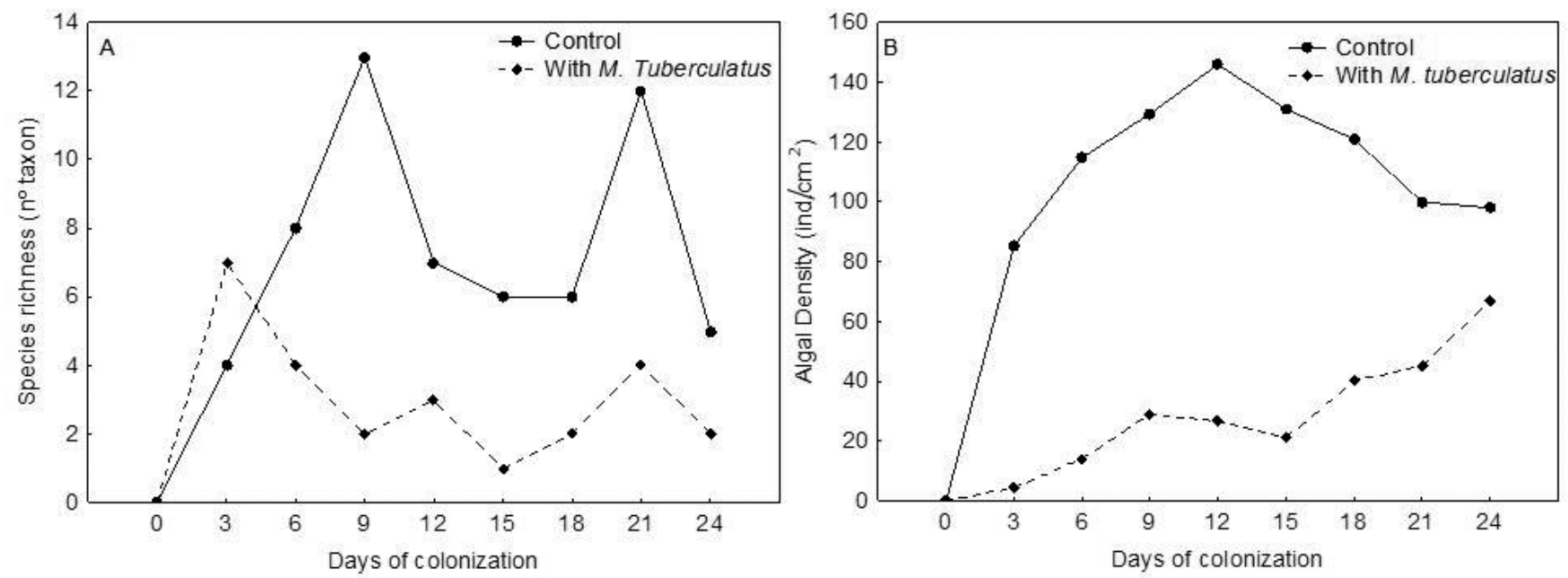

Figure 2. Species richness (A) and density (B) of periphytic algae in the experiment, February 28 - March $23,2012$.

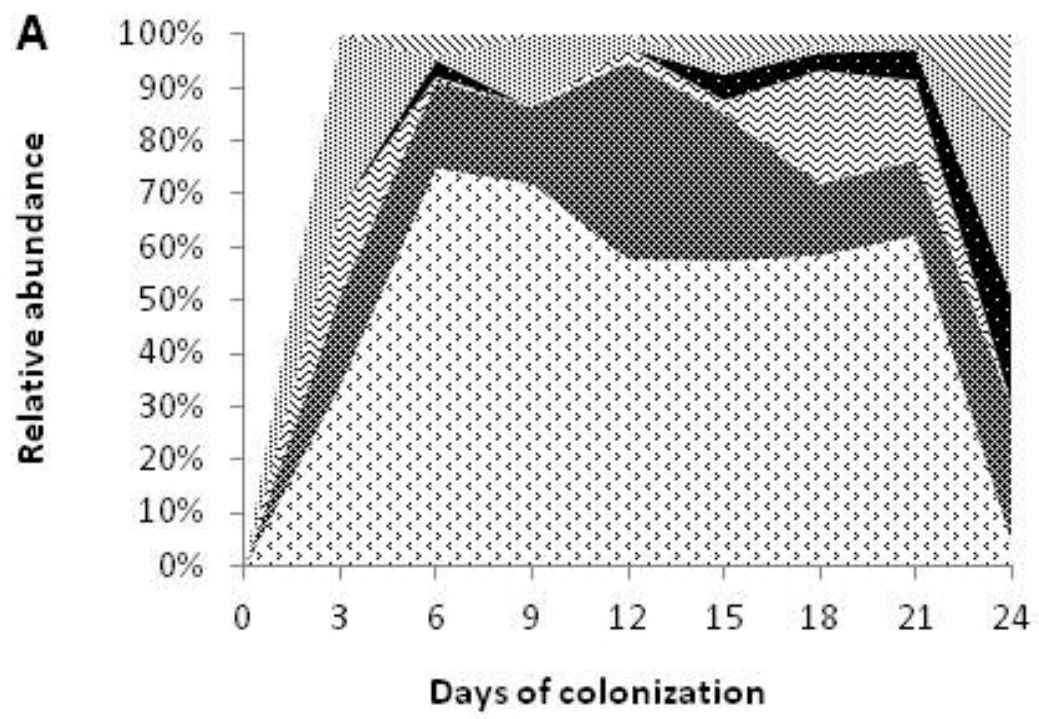

NO Other

Hi: Oedogoniophyceae

Euglenophyceae

$\approx$ Chlorophyceae

Cyanobacteria

$\therefore$ Bacillariophyceae

B $100 \%$

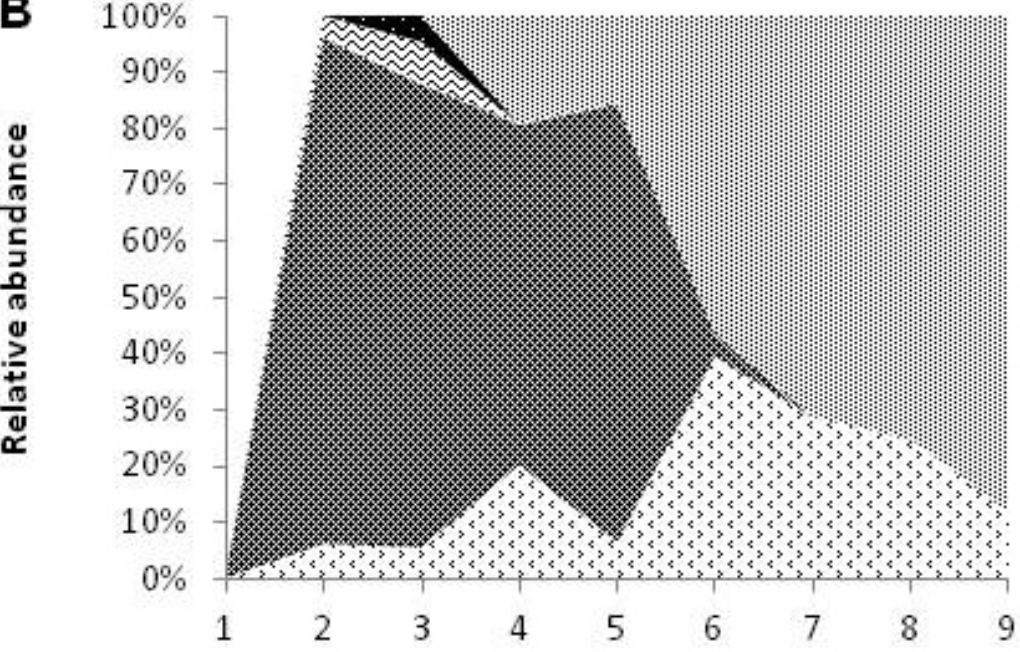

Fin: Florideophyceae

Euglenophyceae

$\approx$ Chlorophyceae

Cyanobacteria

$\therefore$ Bacillariophyceae

\section{Days of colonization}

Figure 3. Relative abundance of the most representative classes of algae in the experiment with control (A) and treatment with Melanoides tuberculatus (B), February 28 - March 23, 2012. 
In the treatment with M. tuberculatus, members of Cyanobacteria were the most abundant (56\% of the total density) followed by Florideophyceae ( $27 \%$ of the total density). Leptolyngbya sp. was dominant in the initial 12 days of colonization, and Chantransia macrospora in subsequent days (Figure 3B). The pressure exerted by the herbivory by $M$. tuberculatus significantly affected the colonization and community structure of periphyton. The biomass of $M$. tuberculatus showed significant growth during the experiment, with an average increase of $2.3 \%$ of the initial biomass. The individuals spawned during the experiment comprised $0.5 \%$ of the final biomass.

The ordering of the nMDS showed significant differences between treatments and time of exposure of the substrate (Figure 4). There was separation of the two cases relating to treatments and between periods, which demonstrated differences in community structure between the period between 1-12 and 15-24 days of colonization for the control treatment, and the period between 1-9 and 12-24 days for the treatment with $M$. tuberculatus (Figure 4). ANOSIM analyses confirmed the significant differences between the periods (Global $\mathrm{R}=$ $0.37 ; \mathrm{p}<0.05)$ and treatments (Global $\mathrm{R}=0.33 ; \mathrm{p}<0.05$ ).

\section{Discussion}

The periphytic algal community is a key element in aquatic ecosystems. This community can contribute about $90 \%$ of total primary production of the ecosystem (Wetzel 1990). In addition, periphyton is a base food for food webs, being rich in protein, vitamins and minerals (Fernandes \& Esteves 1996), and a food source for fish and benthic invertebrates (Morley et al. 2008).

Jones \& Sayer (2003) showed that periphyton biomass is determined by predation by benthic invertebrates. In our study, the density of periphyton decreased when exposed to M. tuberculatus. As noted by Putz (1997) for a study in the Rio Negro, periphytic diatoms are under pressure by many invertebrates feeding on them. Our study showed that the low density of diatoms in the experiment containing $M$. tuberculatus resulted from the feeding of this mollusk. The occurrence of exclusive taxa in the control experiment can be explained by the influence of $M$. tuberculatus on their development, since from the beginning of the experiment, these snails eat the very species that promote subsequent colonization by other taxa.

The significant increase in biomass of $M$. tuberculatus was provided both by the weight gain of the adults and the birth of young individuals. Keller et al. (2007) found that each adult M. tuberculatus could produce around 365 juveniles per year. The high rate of population growth is one reason for the adaptive success of $M$. tuberculatus, not least because these organisms are parthenogenetic.

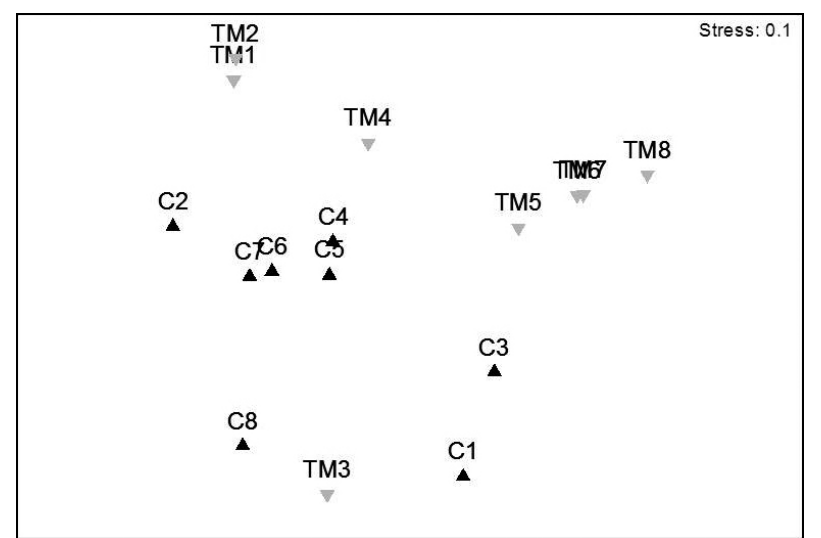

Figure 4. nMDS analysis showing segregation between days of experiment and the treatments.
The decrease in the diversity and richness of the periphyton is explained by the predation pressure exerted by this mollusk. This suggests that in the natural environment, the presence of M. tuberculatus decreases ecological quality (Rosenberg \& Resh 1993), since it caused the disappearance of some species of periphyton, causing other species to become dominant, such as Chantransia and Leptolyngbya. Thus, predation pressure on the periphyton community can alter the trophic dynamics in aquatic ecosystems.

Interestingly, in the first days of the experiment, species richness increased in the treatments with $M$. tuberculatus. This can be explained by the probable presence of periphyton on the shell of the mollusk. This hypothesis is supported by a study of Vasconcelos et al. (In preparation) which showed the association of Chantransia ('macrospora'), an exotic species to the semi-arid northeast, with the shell of M. tuberculatus. Another likely reason for this dominance is the occurrence of Chantransia ('macrospora') only in the treatment containing M. tuberculatus.

The presence of exotic mollusks in aquatic ecosystems is of concern because it threatens local biodiversity, and may cause health problems, for instance, these snails are a host of exotic trematodes such as Centrocestus formosanus (Souto et al. 2011). In addition to predation pressure on periphyton, this snail competes for resources with native gastropods, causing the reduction or disappearance of their populations (Cowie 2001, Prenter et al. 2004). M. tuberculatus was reported causing reduction in populations of Biomphalaria glabrata, a native mollusk, because species competing for habitat and food resources (Rocha-Miranda \& Martins-Silva 2006, Tuan 2009). In the present study, M. tuberculatus reduced the taxa richness and of the periphyton and also affected the density of this community. Since these organisms feed mainly on periphytic algae (Pointier et al. 1991), one can extrapolate this observation to natural environments. However, more studies are needed to explain the consequences of the predation on food chain.

\section{References}

BEESTON, D.C. \& MORGAN, E. 1979. A crepuscular rhythm of locomotor activity in the freshwater prosobranch, Melanoides tuberculata (Müller). Anim. Behav. 27:284-291. http://dx.doi.org/10.1016/00033472(79)90148-9

BICUDO, D.C. 1990. Considerações sobre metodologias de contagem de algas do perifíton. Acta Limnol. Bras. 3:459-475.

BLANCHET, S., LOOT, E.G. \& DODSON, J.J. 2008. Competition, predation and flow rate as mediators of direct and indirect effects in a stream food chain. Oecologia 157:93-104. PMid:18465148. http://dx.doi.org/10.1007/ s00442-008-1044-8

BROWN, D.S. 1994. Freshwater snails of Africa and their medical importance. 2. ed. Taylor \& Francis, London, 608p.

COWIE, R.H. 2001. Can snails ever be effective and safe biocontrol agents? Int. J. Pest Manag. 1:23-40. http://dx.doi.org/10.1080/09670870150215577

FACON, B., GENTON, B.J., SHYKOFF, J., JARNE, P., ESTOUP, A. \& DAVID, P. 2005. A general eco-evolutionary framework for understanding bioinvasions. Trends Ecol. Evol. 21:130-135. PMid:16701488. http:// dx.doi.org/10.1016/j.tree.2005.10.012

FERNANDES, V.O \& ESTEVES, F.A. 1996. Temporal variation of dry weight, organic matter, chorophyll a + phaeopigments and organic carbono $f$ the periphyton on leaves of Typha dominguensis. Arch. hydrobiol. Suppl.bd. Algol. Stud. 81:85-98.

FERNANDEZ, M.A., THIENGO, S.C. \& SIMONE, L.R.L. 2003. Distribution of the introduced freshwater snail Melanoides tuberculatus (Gastropoda: Thiaridae) in Brazil. Nautilus 117:78-82. 
GIOVANELLI, A., VIEIRA, M.V. \& DA SILVA, C.L.P.A.C. 2003. Apparent Competition Through Facilitation between Melanoides tuberculatus and Biomphalaria glabrata and the Control of Schistosomiasis. Mem. Inst. Oswaldo Cruz 98:429-431. PMid:12886429. http://dx.doi.org/10.1590/ S0074-02762003000300025

GUIMARÃES, C.T., SOUZA, C.P. \& SOARES, D.M. 2001, Possible Competitive Displacement of Planorbids by Melanoides tuberculatus in Minas Gerais, Brazil. Mem. Inst. Oswaldo Cruz 96(Suppl.):173-176. http://dx.doi.org/10.1590/S0074-02762001000900027

JONES, J.I. \& SAYER, C.D. 2003. Does the fish-invertebrateperiphyton cascade precipitate plant loss in shallow lakes? Ecology 84:2155-2167. http://dx.doi.org/10.1890/02-0422

KELLER, R.P., DRAKE, J.M. \& LODGE, D.M. 2007. Fecundity as a basis for risk assessment of nonindigenous freshwater mollusks. Consery Biol. 21:191-200. PMid:17298525. http://dx.doi.org/10.1111/j.15231739.2006.00563.x

MORLEY, L., LEACH, F. \& LUGG, R. 2008. Democratising Higher Education in Ghana and Tanzania: Opportunity Structures and Social Inequalities. Int. J. Educ. Dev. 29:56-64. http://dx.doi.org/10.1016/j. ijedudev.2008.05.001

MOSCHINI-CARLOS, V., HENRY, R. \& POMPÊO, M.L.M. 2000. Seasonal variation of biomass and productivity of the periphytic community on artificial substrata in the Jurumirim Reservoir (São Paulo, Brazil). Hydrobiologia 434:35-40. http://dx.doi.org/10.1023/A:1004086623922

PILSBRY, H.A. \& BEQUAERT, J. 1927. Aquatic Mollusks of Belgian Congo. Bull Am. Mus. Nat. Hist. 53:59-602.

POINTIER, J.P., TOFFART, J.L. \& LEFÈVRE, M. 1991. Life tables of freshwater snails of the genus Biomphalaria (B. glabrata, B. alexandrina, B. straminea) and of one of its competitors Melanoides tuberculata under laboratory conditions. Malacologia 33:43-54.

POINTIER, J.P., SAMADI, S., JARNE, P. \& DELAY, B. 1998. Introduction and spread of Thiara granifera (Lamarck, 1822) in Martinique, French West Indies. Biodivers. Conserv. 7:1277-1290. http://dx.doi. org/10.1023/A:1008887531605

PRENTER, J., MacNEIL, C., DICK, J.T.A. \& DUNN, A.M. 2004. Roles of parasites in animal invasions. Trends Ecol. Evol. 7:385-390. PMid:16701290. http://dx.doi.org/10.1016/j.tree.2004.05.002

PUTZ, R. 1997. Periphyton communities in Amazonian black and whitewater habitats: community structure, biomass and productivity. Aquat. Sci. 59:74-93. http://dx.doi.org/10.1007/BF02522552
ROCHA-MIRANDA, F. \& MARTINS-SILVA, M.J. 2006. First record of the invasive snail Melanoides tuberculatus (Gastropoda: Prosobranchia: Thiaridae) in the Paranã River basin, GO, Brazil. Braz. J. Biol. 4:11091115. http://dx.doi.org/10.1590/S1519-69842006000600018

ROS, J. 1979. Prácticas de Ecologia. Ed. Omega, Barcelona, 181p.

ROSENBERG, D.M. \& RESH, V.H. 1993. Freshwater biomonitoring and benthic macroinvertebrates. Chapman \& Hall, 488p.

SANTOS, C.M. \& ESKINAZI-SANT'ANNA, E.M. 2010. The introduced snail Melanoides tuberculatus (Muller, 1774) (Mollusca: Thiaridae) in aquatic ecosystems of the Brazilian Semiarid Northeast (PiranhasAssu River basin, State of Rio Grande do Norte). Braz. J. Biol. 70:1-7. PMid:20231954. http://dx.doi.org/10.1590/S1519-69842010000100003

SANTOS, S.B., MIYAHIRA, I.C. \& LACERDA, L.E.M. 2007. First record of Melanoides tuberculatus (Müller, 1774) and Biomphalaria tenagophila (d'Orbigny, 1835) on Ilha Grande, Rio de Janeiro, Brazil. Biota Neotrop. 7:361-364. http://dx.doi.org/10.1590/S167606032007000300037

SOUTO, L.S., BRITO, M.F.G. \& ROSA, L.C. 2011. Melanoides tuberculatus (Muller, 1774): a new threat to the conservation of aquatic species in Sergipe, Brasil. Scient. Plena 7:1-6.

SZABÓ, K., MAKK, J., KISS, K.Q., EILER, A., ÉVA, A., TOTH, B., KISS, A.K. \& BERTILSSON, S. 2008. Sequential colonization of river periphyton analysed by microscopy and molecular fingerprinting. Freshw. Biol. 1-13.

VAZ, J.F., TELES, H.M.S., CORREA, M.A. \& LEITE, S.P.S. 1986. Ocorrência no Brasil de Thiara (Melanoides) tuberculata (O.F. Muller, 1774) (Gastropoda, Prosobranchia), primeiro hospedeiro intermediário de Clonorchis sinensis (Cobbold, 1875) (Trematoda, Plathyhelmintes). Rev. Saúde Pública 20:318-322.

TUAN, R. 2009. Distribuição e diversidade de espécies do gênero Biomphalaria em microrregiões localizadas no Médio Paranapanema, São Paulo, SP, Brasil. Biota Neotrop. 1:279-283.

UTERMÖHL, H. 1958. Zur Vervolkomnung der quantitativen Phytoplankton: methodik. Int. Ver. Theor. Limllol. 9:1-38.

WETZEL, R.G. 1990. Land-water interfaces: metabolic and limnological regulators. Verh. Int. Ver Limnol. 24:6-24. 
